\title{
The Influence Of Explosive Power, Speed Of Reaction, And Perception Kinesthetic Against The Precision of Target Puncture On The Fencer Foil West Sumatra
}

\author{
$1^{\text {st }}$ Sri Rizki Handayani ${ }^{1}, 2^{\text {nd }}$ Aldilla Yulia Wiellys Sutikno ${ }^{2}$ \\ \{sririzkihandayani.srh@gmail.com ${ }^{1}$, aldilla.wiellys@gmail.com² \\ Universitas Pendidikan Muhammadiyah Sorong, West Papua, Indonesia
}

\begin{abstract}
The purpose of this research was to determine whether or not to influence the direct between explosive power of leg, speed of reactions and perception kinesthetic against the precision of target puncture. This research was conducted on fencer foil West Sumatra. Take Sampling was done by using the total sample technique (total sampling), the total was 12 athletes. The hypothesis test of the influence explosive power of leg to precision of target puncture by $\left(\rho_{1 y}\right)=0,372$. Influence speed of reactions to the precision of target puncture by $\left(\rho_{2} y\right)=0,171$. Influence of perception kinesthetic on the precision of target puncture by $\left(\rho_{3} y\right)=0,337$. Influence explosive power of leg to the perception kinesthetic by $\left(\rho_{31}\right)=0,414$. The influence speed of reaction on the perception kinesthetic by $\left(\rho_{32}\right) 0,348$. The influence explosive power of leg to the speed of reactions $\left(\rho_{21}\right) 0,640$. The research concludes: There is a positive effect explosive power of leg to the precision of target puncture on the fencer foil West Sumatra. There is a positive influence between the speed of reactions to the precision of target puncture of the fenced foil West Sumatra. There is a positive influence between perception kinesthetic to precision of target puncture on the fencer foil West Sumatra. There is a positive influence between explosive power of leg on the perception kinesthetic of the fencer foil West Sumatra. There is a positive influence between the speed of reactions to perception kinesthetic of the fencer foil West Sumatra. There is positive influenced between explosive power of leg to the speed of reactions to perception in the fencer foil West Sumatra
\end{abstract}

keywords: Precision of Target Puncture, Explosive Power of Leg, Reaction Time and Perception Kinesthetic

\section{Introduction}

Sports can not be separated from our lives and very important because in an effort to improve the quality of human resources. The government make the sport as a means of national development. Sport which consists of two aspects, namely physical and spiritual aspects, if these evolving and growing coherence will gain a harmonious life in its growth. The harmony of physical and spiritual life in humans could be achieved by doing sports.

Fencing is one of martial arts fighting developed since immemorial time ${ }^{1}$. Fencing has been around for 4000 years, the preliminary matches of this sport can be found in the reliefs

${ }^{1}$ Cheris, Elaine. Olahraga Anggar Langkah Menuju Sukses (Jakarta: @Human Kinectics, (2002)., hlm.1. 
carved in Madinet-Habu temple in Luxor, Mesir. The development of fencing in the world, then in 1914 formed the parent organization in the world fencing in Paris Federationale International d'Escreme (FIE), the organization has been the formation of it, then make the game rules of fencing in the world ${ }^{2}$. Then these rules always used as guidelines in a match official, and the regulations are revised in the next FIE congresses until now.

In Indonesia fencing be acquainted with the Dutch in 1922. Meanwhile, according to Rd. Slamet Poerawinata anggar magazine, Fencing is a symbol of war of the kingdom, and long ago Indonesia already had the basics of fencing. During Ken Arok Indonesia is familiar with the kris as a weapon, keleweng, mandong, rencong, etc ${ }^{3}$. The quote above explained fencing has been in Indonesia since ancient times and used for self-defense or fighting.

In the game, there are three types of fencing weapons being manipulated or contested, namely epee, foil and sabel. Fencing has become a dynamic sport and takes many years of training, and takes a keen eye, an open mind and a healthy body in this sport ${ }^{4}$. To that end, in mastering the skill of fencing should be doing the exercise routine and repetitive movements that will earn good automate and simplify the player to master techniques of fencing during training and in matches ${ }^{5}$. Because the top performance in the sports coaching to a process of preparation of the planned gradual, purposeful, systematic, and sustainable. In addition, fencing skills technique is also determined by the facilities and infrastructure available. The fundamental thing is the terrain owned, next is the required infrastructure such as swords, workout clothes, masks, hand skunt, and other tools.

Biomotor factors also important role in determining the mastery of technique and tactics such as basic motor ability and physical elements such as when the motion parry and attack should be fast and precision targeting and directional thrust to opponent's field goal.

The target precision punctures the main thing because accuracy is one aspect motorik capabilities necessary to get the value or point when competing. Right or accuracy is the state, trait precise, precision, pertinence. So accuracy is the ability to control the movements of free against a target. he accuracy can be movement performance or as the accuracy of the result that is closely related to the maturity of the nervous system in the process input or stimulus that comes from outside, such as a place in assessing the space and the time, place in distributing power, wherein coordinating muscles and etc ${ }^{6}$. From the definition, it can be a statement that the accuracy-related and co-ordinate system (nerves) in the human body. The nervous system is organized into the central nervous system and the peripheral nervous system. the brain and spinal cord form the central nervous system ${ }^{7}$. The accuracy puncture target depends on the work of the nervous system are connected by means of sensory and motor when delivering impulse and response to stimuli when the motion follow-up was done after doing the movements are free with the aim of directing the weapon to puncture on the right target.

In a study of the accuracy fencing or hit the target precisely, resulting from three elements: the appropriate footwork, hand gestures accurate and mental choice and good tactics in completing the appropriate course of action ${ }^{8}$. So operationally that the accuracy of the intended targets are placing a sword or puncture into the target areas that have been determined.

\footnotetext{
${ }^{2}$ Nirwandi. Pengetahuan Dasar Olahraga hangar. Padang: Sukabina Press, (2010)., hlm.1.

${ }^{3}$ Ibid., hlm.3.

${ }^{4}$ Ibid., hlm.6.

${ }^{5}$ Syaifuddin. Atlas Berwarna Tiga Bahasa Anatomi Tubuh Manusia. Jakarta: Salemba Imedika. (2010)., hlm.16.

${ }^{6}$ Widiastuti. Tes dan Pengukuran Olahraga. Jakarta : PT Bumi Timur Jaya, (2011)., hlm.17.

${ }^{7}$ McGinnis, Peter M. Biomechanics Of Sport and Exercise. Australia: Human Kinetics, (2005)., hlm. 274.

${ }^{8}$ Loc.cit., cheris., hlm.1.
} 
The puncture target accuracy of fencing one of very important component motorik leg muscle explosive power. Muscle is a connective tissue whose main task is to contract which serves to move the body parts of both the conscious and not ${ }^{9}$. Muscle function in the human body classified into three parts, as follows: locomotor active occurs when the muscle belly of some kind of stimulus, means of transport which will move the muscle contraction bones and forming tools in. The motion caused by the cooperation between the muscles and bones, can not serve as a means of motion if it is not driven by the muscle, the muscle is able to move the bones because it has the ability to contract ${ }^{10}$. So the muscle is a device of motion in the spine where the muscles attach. In motorik skill ability of leg muscle explosive power that influence is the framework and leg muscles to generate explosive power which has the necessary speed and strength exercises.

Explosive power is the result of a merger of power and speed. So the explosive power of a leg muscle strength and speed of the leg muscle contractions in a dynamic and explosive in a short time or as short as possible ${ }^{11}$. With their explosive power leg muscle and goodwill facilitate the player in making step, forward, attack and puncture quickly and get about power or strength were perfect in attack and speed is good at the time of puncture. The reaction speed is also one important element motorik ability in the sport of fencing. Speed as an ability to generate body movements in the shortest possible time. The speed of reaction is a person's ability to answer or respond to a signal or stimulus at high speed. The speed of reaction is divided into two single reaction and the reaction of a compound. Single reaction speed is the ability to respond to stimuli that have been known to the direction and the goal in the shortest time possible. Compound reaction speed is the ability to respond to stimuli of unknown direction and the goal in the shortest time possible. That is, prior to the movement in the minds of existing sports mind perception, but unknown direction and target motion motor plan that will be carried out.

Speed is the ability to walk and run very fast. Speed development also means developing skills, so the technique is carried out at high-speed ${ }^{12}$. Reaction speed is divided into two, namely single reaction and compound reaction. The speed of a single reaction is one's ability to respond to stimuli that have known their direction and target in the shortest possible time. Compound reaction speed is a person's ability to respond to stimuli that have not known the direction and target in the shortest time possible ${ }^{13}$. Reaction speed is related to stimulus exposure and the initiation of muscle movements. reaction speed is the speed of the muscle's ability to react as quickly as possible after receiving a stimulus and responding to a stimulus quickly and precisely ${ }^{14}$. In an attack when making a stab to start an attack, the front foot must leave the ground as in the beginning of the step but must continue further by allowing the leading foot to step fully in length, by maintaining the center of gravity between the legs, the foot rear push straight before the front heel reaches the ground, towards the end the rear arm is extended to add the end of the push and maintain balance, thus the natural angle of the fencer's body causes

\footnotetext{
${ }^{9}$ Wiartoso, Giri. Fisiologi dan Olahraga, Yogyakarta: Graha Ilmu, (2013)., hlm.51.

${ }^{10}$ Wirasasmita, Ricky. Ilmu Urai Olahraga II Optimalisasai Pengembangan Kemampuan Fisik Melalui Konsepsi Keolahragaan. Bandung: Alfabeta. (2014)., hlm.32.

${ }^{11}$ Loc.cit, Widiastuti., hlm.17.

12 Tangkudung, James. Puspitorini, Wahyuningtyas. Kepelatihan Olahraga Pembinaan Prestasi Olahraga Edisi II, (Jakarta: Cerdas Jaya. 2012)., hlm.71.

${ }^{13}$ Sukadiyanto, Dangsina muluk. Pengantar teory dan Metodologi Melatih Fisik. Bandung: Cv.Lubuk

Agung, (2011)., hlm.117.

${ }^{14}$ Gordan, Dan. Coaching Science. Learning Matters: USA. (2009)., hl. 188.
} 
the weight to fall forward which must arrive a fraction of a second before the front heel falls ${ }^{15}$. For this reason, reaction speed is one of the motor elements that must be trained and possessed by a fencing athlete.

In moving, we push weight forward or back, and the fencer must be able to move equally fast in both directions for a split second. So in fencing when doing a parry (rip-riposte) or sudden attack and puncture target accuracy requires a good reaction speed ${ }^{16}$.

In addition to motor ability, kinesthetic perception is needed in carrying out puncture targets in a high technical quality. Somesthetic senses which means sorna means body, aesthetics means feeling. kinesthesia is aware of muscle movements ${ }^{17}$. Kinesthesis is a very complex feeling caused by stimulation in muscles, muscles, and wrists. If the response is a good response, then the ability to obtain a variety of information, abstract thinking, reasoning and act efficiently and effectively to the movements that it does. For this reason, in fencing, it is necessary to have a good kinesthetic element in making quick and right decisions.

Kinesthesis is the ability to feel the position of our body parts in space and in relation to one another ${ }^{18}$. Kinesthetic receptors provide detailed information on head and body orientation, differences in various pressures due to gravity and movements in various parts of the body, body movements, and a number of other forms of information (Gray and Sholl, 2008) ${ }^{19}$. Kinesthetic is a sense that gives awareness about the position of the body or body parts when moving. because of the chiesthetic senses, someone will be able to control movements more accurately. Kinesthetic refers to the understanding of joint motion, tension from orientation in space. The success of motion behavior is very dependent on the ability of individuals to capture information received and send it to various parts of the body to form a response.

Engineering skills in targeting accuracy puncture athletes fencing influenced by several factors, such as the explosive power leg muscle, speed, endurance, coordination, accuracy, as well as the perception of kinesthetic an athlete, as well as fencing athletes of West Sumatra. It aims to determine whether or not the effect of leg muscle explosive power, speed of reaction and kinesthetic perception of the accuracy of the puncture target in athletes foil fencing weapon of West Sumatra.

More specifically the study aims to determine whether there is a direct effect and how much influence on:

1. The direct effect of leg muscle explosive power (X1) to puncture target accuracy (Y) in athletes foil fencing weapon of West Sumatra.

2. The direct effect of reaction speed (X2) to puncture target accuracy (Y) in athletes foil fencing weapon of West Sumatra.

3. The direct effect of perception kinistetik (X3) against the target accuracy puncture (Y) in athletes foil fencing weapon of West Sumatra.

4. The direct effect of leg muscle explosive power (X1) on the perception of kinesthetic (X3) in athletes foil fencing weapon of West Sumatra.

5. The direct effect of reaction speed (X2) on the perception of kinesthetic (X3) in athletes foil fencing weapon of West Sumatra.

${ }^{15}$ John. J. Smith, Foil Fencing the Techniques and Tactics of Modern Foil Fencing (UK: Summersdale Martiel Arts, 2003), h.27.

${ }^{16}$ Adersen, Bob. All About Fencing, London: Stanley Paul, (1970), hlm.46.

${ }^{17}$ Suharso, Ana Retnoningsih. Kamus Besar Bahasa Indonesia. Semarang: Cv.Widya Karya. 2005., hlm. 253

${ }^{18}$ Pastorino, Ellen. Susann Doyle-Portillo, What Is Psychology? Essentials. Canada: Wadsworth, (2013)., hlm.104.

${ }^{19}$ Lahey, Psychology an Introduction. Americas, New York: McGraw Hill, (2012)., hlm.138 
6. The direct effect of leg muscle explosive power (X1) the reaction speed (X2) in athletes' foil fencing weapon of West Sumatra.

\section{Method}

The method used in this study is a quantitative approach, survey methods with engineering measurements and tests, while the technique of analysis using the approach path analysis (path analysis) were used to analyze the patterns of relationships between variables in order to determine the direct effect a set of independent variables (exogenous) the dependent variable (endogenous). The variables studied is composed of four variables consisting of the three exogenous variables and the endogenous variables. Exogenous variables consisted of leg muscle explosive power (X1), the reaction rate (X2) and kinesthetic perception (X3). Endogenous variables consist of targeting accuracy puncture $(\mathrm{Y})$.

The pattern of association between the variables shown in the following picture:

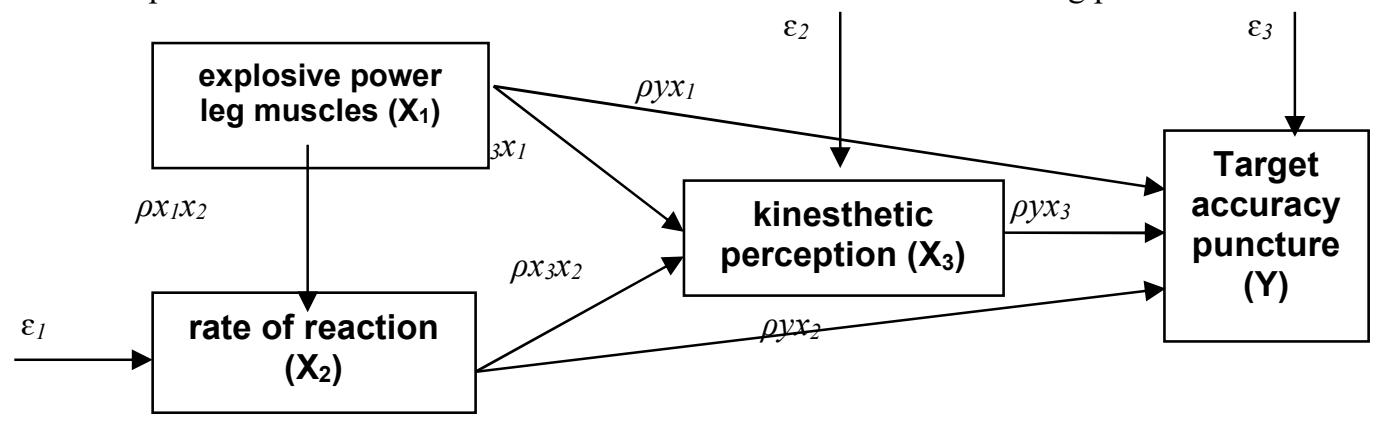

Figure 1: The constellation of analytical techniques for the hypothesis X1, X2, X3, and Y.

Data collection techniques using test and measurement techniques. The data obtained is the result of the measurement of leg muscle explosive power, speed of reaction, kinesthetic perception and precision targeting weapons puncture foil fencing athlete West Sumatra.

Form data in this research is a form of numbers include: data from a leg muscle explosive power, speed of reaction and kinesthetic perception and target accuracy prick test results. Formulating appropriate research methodology and theoretical models that have been described earlier, the analytical techniques used in testing the hypothesis is path analysis.

Analysis of the data include: (1) a description of the data, (2) testing requirements analysis of the test data normality and homogeneity of variance of data, (3) linearity test and regression significance test of regression, (4) the path analysis (path analysis) which includes: testing models, hypothesis testing.

\section{Result}

Description of the data from the study aims to provide a general overview of the distribution of the data. The prices are presented after being processed out of raw data using descriptive statistical methods, ie the maximum value, minimum value, range, average, standard deviation, and variance. 
Table 1. Summary of results of research

\begin{tabular}{l|c|c|c|c}
\hline \multirow{2}{*}{\multicolumn{1}{c|}{ Information }} & \multicolumn{4}{c}{ Variable } \\
\cline { 2 - 5 } & $\begin{array}{c}\text { Explosive } \\
\text { power leg } \\
\text { muscles }\left(\mathrm{X}_{1}\right)\end{array}$ & $\begin{array}{c}\text { Reaction } \\
\text { Speed }\left(\mathrm{X}_{2}\right)\end{array}$ & $\begin{array}{c}\text { kinesthetic } \\
\text { perception } \\
\left(\mathrm{X}_{3}\right)\end{array}$ & $\begin{array}{c}\text { Target } \\
\text { accuracy } \\
\text { puncture }(\mathrm{Y})\end{array}$ \\
\hline Total Sample $(\mathrm{n})$ & 26 & 26 & 26 & 26 \\
\hline Total & 6263 & 4 & 217 & 346 \\
\hline Max value & 261 & 0,1916 & 10 & 18 \\
\hline Min value & 222 & 0,1010 & 6 & 8 \\
\hline Range & 39 & 0,09 & 4 & 10 \\
\hline Average $(\mathrm{X})$ & 240,88 & 0,14 & 8,35 & 13,31 \\
\hline standard deviation (SD) & 11,63 & 0,02 & 0,89 & 2,66 \\
\hline Variants $\left(s^{2}\right)$ & 135,38 & 0,00068 & 0,79 & 7,10 \\
\hline
\end{tabular}

The data in this study using a statistical test by using path analysis (path analysis), also with the test requirements of the normality test, homogeneity, linearity regression and significance of regression. And also test the hypothesis by using SPSS version 17.00 with a summary of the statistical calculation as follows:

Table 2. Summary of the decomposition of the path coefficient

\begin{tabular}{l|l|l|l|l}
\hline $\begin{array}{l}\text { Direct influence between } \\
\text { variables }\end{array}$ & path coefficient & Account & p-value & Knot \\
\hline $\mathrm{X}_{1}$ to $\mathrm{Y}\left(\rho_{1 \mathrm{y}}\right)$ & 0,372 & 0,928 & 0,007 & Sig. \\
\hline $\mathrm{X}_{2}$ terhadap $\mathrm{Y}\left(\rho_{2 \mathrm{y}}\right)$ & 0,171 & 0,906 & 0,009 & Sig. \\
\hline $\mathrm{X}_{3}$ terhadap $\mathrm{Y}\left(\rho_{3 y}\right)$ & 0,337 & 0,797 & 0,026 & Sig. \\
\hline $\mathrm{X}_{1}$ terhadap $\mathrm{X}_{3}\left(\rho_{31}\right)$ & 0,414 & 2,104 & 0,003 & Sig. \\
\hline $\mathrm{X}_{2}$ terhadap $\mathrm{X}_{3}\left(\rho_{32}\right)$ & 0,548 & 1,769 & 0,00 & Sig. \\
\hline $\mathrm{X}_{1}$ to $\mathrm{X}_{2}\left(\rho_{21}\right)$ & 0,640 & 4,085 & 0,00 & Sig. \\
\hline
\end{tabular}

\section{Discussion}

Based on the results of testing of all hypotheses that have been done, it can be stated that:

First, based on the results of hypothesis testing individual turns of leg muscle explosive power, speed of reaction and kinesthetic perception affect significantly the accuracy of the puncture target in athletes foil fencing weapon of West Sumatra. Structural equation derived from the analysis of the path of leg muscle explosive power, speed of reaction and kinesthetic perception of the target accuracy puncture results are as follows: $Y=0.007 \rho 2 y \rho 1 y+0.009+$ $0.026+0.64 \rho 3 y \varepsilon 3$.

Effect of leg muscle explosive power variable (X1) to puncture target accuracy (Y) directly at $0.3722 \times 100 \%=0.1383$ or $13.83 \%$. Variable speed of reaction (X2) to puncture target accuracy $(\mathrm{Y})$ has a direct influence of $0.1712 \times 100 \%=0.0292$ or $2.92 \%$. While kinesthetic perception variable (X3) against the target accuracy puncture $(\mathrm{Y})$ has a direct influence for at 0 , $3372 \times 100 \%=0.1136$ or $11.36 \%$.

From Urian above can be seen how much influence variable explosive power leg muscle, speed of reaction and perception of kinesthetic against targeting accuracy jab, for that there are still other variables that can affect the accuracy of target puncture include a technique to 
puncture the target effectively and efficiently in accordance with the stages such as body position, limb movements, hand gestures, movement coordination, nor Mr movement hoax in achieving value or point.

Secondly, the hypothesis of a significant influence of leg muscle explosive power and speed reaction against kinesthetic perception after testing the hypothesis is proven individually significantly affect kinesthetic perception in athletes' foil fencing weapon of West Sumatra. Structural equation derived from the analysis of the path of leg muscle explosive power against kinesthetic perception and reaction speed against kinesthetic perception is $\rho 31 \mathrm{X} 3=0.003+$ $0.000+0.72 \varepsilon 2 \rho 32$.

Variable effect of leg muscle explosive power directly to the kinesthetic perception by 0 , $4142 \times 100 \%=0.1713$ or $17.13 \%$. Reaction speed direct influence on the kinesthetic perception of $0.3482 \times 100 \%=0.1211$ or $12.11 \%$. From Urian can be seen the effect of variable explosive power leg muscles and reaction speed directly against the perception of bodily rest is the influence of other variables that can affect the perception of kinesthetic include internal factors include the nature of athletes, past experience and ideals, while factor external covering infrastructure, training, and environmental programs.

Third, the hypothesis significant effect of leg muscle explosive power against speed reaction after testing the hypothesis is proven individually significant effect on the speed of the athlete reaction foil fencing weapon of West Sumatra. Structural equation derived from the analysis of the path of leg muscle explosive power of the reaction speed is x $2=0.000+0.60 \varepsilon 1$ p21.

Variable effect of leg muscle explosive power directly to the speed of reaction of 0.6402 $\mathrm{x} 100 \%=0.406$ or $40.96 \%$. Of those Urian can be seen the effect of variable leg muscle explosive power directly to the speed of reaction of the rest is the influence of other variables that can affect the reaction speed is a factor other motorik.

From the results above description can be seen the results of research on the effect of leg muscle explosive power, speed of reaction and kinesthetic perception of the accuracy of the puncture target in athletes foil fencing weapon of West Sumatra. These findings suggest that a fencing athlete must have a leg muscle explosive power, speed of reaction and good kinesthetic perception of course, where all three have an effect in improving the targeting accuracy puncture.

\section{Research Limitations}

In this research has made various efforts to avoid things that can reduce the weight and the results of research. However, it is recognized there are still some weaknesses, among others:

1. The lack of control over other variables, thus allowing other variables that can affect. In the technical implementation of this research is very difficult to control the sample. Because this study did not use the method of experimental research.

2. This study is limited three independent variables (exogenous), the leg muscle explosive power, speed of reaction and kinesthetic perception. While there are many other factors that affect the increase in puncture target accuracy as the dependent variable (endogenous).

3. Samples were examined in this study is only carried out on athletes weapons floret West Sumatra as many as 26 people. Therefore, it is necessary to study similar to include a broader sampling. 
4. In this study involve the physical aspect, the mental aspect which consists of leg muscle explosive power, speed of reaction, kinesthetic perception and precision targeting puncture. In addition, anthropometric aspects such as height and leg length and other technical aspects are not investigated. Although this research is already significant statistically, with the addition of other variables would influence will be increased.

\section{Implications}

The implication of this study is made of the conclusions of the study and the reflection of the research findings as follows:

1. Research Implications

Given this research, it can be used as a basis to investigate further with respect to variables therein. However, this study is not the only one to be a reference for further research in IKASI West Sumatra.

2. Theoretical Implications

The study reinforces the knowledge and theory that variable leg muscle explosive power, speed of reaction and kinesthetic perception influence variable puncture target accuracy. In this regard, the results obtained are consistent with the theoretical model proposed.

3. Practical implications

In the process of studying the motion many influential factors, such as factors of athletes, training factors, environmental factors and factors of coaches, and management. Factors athletes is a major determining factor in the learning process of motion because basically, every individual has the qualities and attributes that are different from each other.

\section{Conclusion}

Drawing conclusions based on the findings of research conducted by the exogenous variables consisted of leg muscle explosive power (X1), the reaction rate (X2) and kinesthetic perception (X3). Endogenous variables consist of targeting accuracy puncture (Y).

1. There is an effect of leg muscle explosive power (X1) to puncture target accuracy (Y) in athletes' foil fencing weapon of West Sumatra.

2. There is an influence between the reaction speed (X2) to puncture target accuracy (Y) in athletes' foil fencing weapon of West Sumatra.

3. There is an influence between perception kinesthetic (X3) targeting accuracy puncture (Y) in athletes' foil fencing weapon of West Sumatra.

4. There is an effect of leg muscle explosive power (X1) on the perception of kinesthetic (X3) in athletes' foil fencing weapon of West Sumatra.

5. There is an influence between the reaction speed (X2) on the perception of kinesthetic (X3) in athletes' foil fencing weapon of West Sumatra.

6. There is an effect of leg muscle explosive power (X1) to the speed of the reaction (X2) in athletes' foil fencing weapon of West Sumatra.

Thus the targeting accuracy of weapons stab at fencing athlete floret West Sumatra could be improved through increased leg muscle explosive power, speed of reaction and kinesthetic perception 


\section{References}

[1] Andersen, Bob. All About Fencing, London: Stanley Paul, (1970)

[2] Budiyono, Setiadi . Anatomi Tubuh Manusia. Bekasi: Laskar Aksara. (2011)

[3] Cheris, Elaine. Olahraga Anggar Langkah Menuju Sukses (Jakarta: @Human Kinectics, (2002)

[4] Coon, Dennis and John O. Mitterer, Introduction To Psychology Active Learning Through Modules, China: Wadsworth Cengage Learning, (2012)

[5] Gordan, Dan. Coaching Science. Learning Matters: USA. (2009)

[6] Lahey, Psychology an Introduction. Americas, New York: McGraw Hill, (2012)

[7] McGinnis, Peter M. Biomechanics Of Sport and Exercise. Australia: Human Kinetics, (2005)

[8] Nirwandi. Pengetahuan Dasar Olahraga anggar. Padang: Sukabina Press, (2010)

[9] Pastorino, Ellen. Susann Doyle-Portillo, What Is Psychology? Essentials. Canada: Wadsworth, (2013)

[10] Smits, John Jos, Foil Fencing the Techniques and Tactics of Modern Foil Fencing, UK: Summersdale Martiel Arts, (2003)

[11] Sukadiyanto, Dangsina muluk. Pengantar teori dan Metodologi Melatih Fisik. Bandung: Cv.Lubuk Agung, (2011)

[12] Suharso, Ana Retnoningsih. Kamus Besar Bahasa Indonesia. Semarang: Cv.Widya Karya. (2005)

[13] Syaifuddin. Atlas Berwarna Tiga Bahasa Anatomi Tubuh Manusia. Jakarta: Salemba Imedika. (2010)

[14] Tangkudung, James. Puspitorini, Wahyuningtyas. Kepelatihan Olahraga Pembinaan Prestasi Olahraga Edisi II, (Jakarta: Cerdas Jaya. 2012)., hlm. 71

[15] Widiastuti. Tes dan Pengukuran Olahraga. Jakarta : PT Bumi Timur Jaya, (2011)

[16] Wiartoso, Giri. Fisiologi dan Olahraga, Yogyakarta: Graha Ilmu, (2013)

[17] Wirasasmita, Ricky. Ilmu Urai Olahraga II Optimalisasai Pengembangan Kemampuan Fisik Melalui Konsepsi Keolahragaan. Bandung: Alfabeta. (2014) 